\title{
Trends in Stone Fruit Cultivar Development
}

\author{
David H. Byrne
}

Additional index words. Prunus, peach, nectarine, plum, apricot, breeding, marketing, health, tree architecture, low chilling, postharvest, quality

Summary. Despite the hundreds of existing stone fruit (Prunus spp.) cultivars used for fresh market, there is a continuing need to develop new stone fruit cultivars as the requirements of the industry change. Over the last 20 years there has been a shift toward private breeding as the public sector decreases its support of these longrange programs. As a result there are fewer public breeding programs and many of those still operating protect their releases and partially fund their programs with royalty payments. Other trends that are shaping the development of new stone fruit cultivars are a need for smaller or more easily managed tree architecture, a trend toward the use of fewer agricultural chemicals, the expansion of production zones into the milder winter zones to allow year-round availability of stone fruit, a general diversification of fruit types being marketed, the increased awareness of the health benefits of fruit consumption, the need for better and more consistent quality, and given the global marketing of these fruit the increased need for enhanced postharvest qualities. The breeding programs of the world are responding to these trends and working toward developing the cultivars for the world markets of the future.

$\mathrm{T}$ There are hundreds of peach, nectarine (Prunuspersica), $\operatorname{plum}(P$. salicina and hybrids), apricot ( $P$. armeniaca), and cherry ( $P$. avium and $P$. cerasus) cultivars used in the U.S. and throughout the world. The nurseries in the southeastern U.S. usually list between 50 to 150 peach and nectarine cultivars and the California Tree Fruit Agreement (CTFA) lists 
80-85 major cultivars of peach and an equal number of the nectarine (CTFA, 2003). The USDA Handbook published by W.R. Okie (1998) describes 700 peach and nectarine cultivars and the Brooks and Olmo Register of Fruit and Nut Varieties (ASHS, 1997) lists about 300 nectarine and 1000 peach cultivars. These are only those in the North America. In the world, breeders have been releasing about 100 peach and nectarine, about 20 apricot, about 30 plum, and about 20 cherry cultivars every year for the last 10 years (Della Strada and Fideghelli, 2003; Della Strada et al., 1996; Fideghelli et al., 1998). Do we need all of these cultivars? No, many are obsolete. Do we need more cultivars? Yes, we need more because our markets are changing, our production systems are changing, and our orchard locations are changing.

Who develops these cultivars? About $50 \%$ of the peach, nectarine and japanese plum cultivars released in the world are developed in the U.S. Europe, mainly France and Italy, produces about $30 \%$ of the cultivars. Lesser amounts are developed in South Africa, Australia, Asia (mainly China and Japan), and Latin America (mainly Mexico and Brazil). These percentages have been fairly steady over the last 20 years (Della Strada et al., 1996; Della Strada and Fideghelli, 2003; Fideghelli et al., 1998), however there is increased breeding activity in Asia, Australia, and Latin America as well as a more global approach to the testing and marketing of new cultivars from established programs (Byrne et al., 2000).

There are eight major trends that are molding the present breeding programs in various ways. These are:

1.Decrease in public breeding programs

2. Changing tree architecture

3. Increased concerns about the use of agricultural chemicals zones

4.Expansion of production

5.Diversification of fruit types

6. Increased interest in the health benefits of fruit

7.Increased demand for fruit quality traits

8. Need for better postharvest

\section{Decrease in public breeding programs}

Public peach and nectarine breeding programs are releasing a smaller percentage (from $45 \%$ to $31 \%$ of total since 1980) of the cultivars as compared to private breeding programs (Della Strada and Fideghelli, 2003; Della Strada et al., 1996; Fideghelli et al., 1998). In the U.S. about $50 \%$ of the public stone fruit breeding programs have closed since 1970. Most of the remaining public breeding programs do not release new cultivars without protection as in the past, but rather raise money by patenting their releases and by forming collaborations with private partners to test and market new cultivars. Although these arrangements are working, it has led to less germplasm exchange among the public breeding programs.

In the U.S., private breeding programs devote less than $10 \%$ of their budgets to either germplasm development or genetic research, whereas over $60 \%$ of the efforts of public breeding programs are in these areas (Table 1) (Frey, 1996, 1998). Thus, as breeding programs close, there is also a decrease in basic research in germplasm development, genetics and breeding technology that is primarily funded by governmental research granting programs. Recently, due to the lobbying efforts of the American Seed Trade Association, there was an increase in allocations for our national germplasm system which has benefited the stone fruit industry tremendously. Nevertheless, genomic and other research in fruit crops as compared to agronomic crops is minimal. Since the success of a grant proposal can depend on industry support, the stone fruit industry needs to get more involved to encourage consistent and increased governmental funding for this research which will ensure the long-range success of breeding programs.

\section{Changing tree architecture}

The high cost of labor, especially in developed countries, has lead to research emphasis on modifying tree size or growth, simplifying training techniques, and the mechanization of fruit tree production. Much work has been done in the development of new training systems, chemical control of growth, and growth controlling rootstocks over the last 20 years.

There are two genetic approaches. One is to develop dwarfing rootstocks as has been successfully done for apple (Malus $\times$ domestica). In stone fruit, there is considerable interest in this area and dwarfing rootstocks are beginning to make an impact on plum, peach, and cherry production not only due to smaller tree size but also to more precocious fruit bearing from a budded tree (Lang, 2000; Reighard, 2000).

The other approach is to modify the scion tree architecture. This ranges from selecting within the standard growth type for better branching habit and increased spur formation (Kervella et al., 1998a; Martinez-Gomez et al., 2003; Pascal and Monteux-Caillet, 1998; Scorza, 1987) to developing cultivars with unique tree architecture (Scorza et al., 1989). These new growth habits range from dwarf, semi-dwarf, compact, pillar, and weeping (Bassi et al., 1994; Byrne, 2002; Giovannini et al., 1994; Liverani and Giovannini, 2000; Monet et al., 1988; Scorza, et al., 1989). Whatever the approach, the optimal training system needs to be developed for each unique tree architecture (Bassi et al., 1994; Scorza et al., 1986; Tworkoski and Scorza, 2001) and marketing will need to bundle these unique cultivars with the optimal training systems.

\section{Increased concerns about the use of agricultural chemicals}

Concern about the safety of agricultural workers, the potential of environmental contamination, and the safety of the consumer has spurred the development of tighter governmental restrictions on the use of agricultural chemicals and on alternate pest and disease control strategies. Pesticide residues on stone fruit are a concern of many consumers, as indicated by several recent surveys (Clareton, 2000; Wei, 2001) and the growing market for organic produce (Dimitri and Greene, 2002). The future will bring more residue testing of fruit and more producer accountability for chemical residues found on the fruit.

Table 1. Public vs. private breeding programs in temperate fruit and nut crops (Frey, 1996, 1998).

\begin{tabular}{lll}
\hline Activity & Public & Private \\
\hline $\begin{array}{l}\text { Cultivar } \\
\text { development }\end{array}$ & $36 \%$ & $91 \%$ \\
$\begin{array}{l}\text { Germplasm } \\
\text { enhancement }\end{array}$ & $36 \%$ & $6 \%$ \\
Genetic research & $28 \%$ & $3 \%$ \\
Total effort & & \\
$\quad$ (scientist-years) & 73 years & 32 years \\
\hline
\end{tabular}


This has lead to extensive work in integrated pest and disease management systems to reduce the amount of pesticides and fungicides used in the production of stone fruit. One facet of these management systems is the use of genetic resistance to various diseases and pest problems. Examples are the active scion breeding programs for resistance to brown rot caused by Monilinia fructicola and M. laxa (California, Mexico, Brazil, Italy), powdery mildew caused by Sphaerotheca pannosa (Mexico, France, Italy), aphids (Myzus persicae) (France, Italy), bacterial leaf spot caused by Xanthomonascampestris pv. pruni (southeastern U.S., humid South America, Asia), and plum pox caused by the sharka virus (Europe), among others (Bellini et al., 1996; Byrne et al., 2000; Gradziel et al., 1998; Kervella et al., 1998b; Monet et al., 1998). Breeding for rootstocks for resistance to nematodes (Meloidogyne and Pratylenchus) (Claverie et al., 2004; Lu et al., 2000; Pinochet et al., 2000 ), peach tree short life (Nyczepir and Beckman, 2000), armillaria root rot (Armillaria spp.; Beckman and Pusey, 2001), Phytophthora and various other edaphic problems (tolerance to calcareous, heavy, and waterlogged soils) is also being actively pursued.

One of the most often cited objectives of biotechnology is to use molecular markers for the selection of resistance genes and to insert genes for resistance into a plant. There has been excellent progress in identifying markers for resistance genes to nematodes and powdery mildew (Foulonge et al., 2003; Lecouls et al., 2004; Yamamoto and Hoyashi, 2002 ) although their incorporation into breeding programs is still in its infancy. The use of transformation to increase the disease resistance of stone fruit is, unfortunately, technically very challenging. Nevertheless, it has led to a plum pox-resistant European plum cultivar, which is currently being field tested (Scorza, 2000). Once these techniques are better developed, transformed cultivars could lead to reduced pesticide use, but the public acceptance of such cultivars is still not known.

\section{Expansion of production zones}

Presently produce is marketed globally to ensure a year-round supply of each produce item. This has spurred research into extending the harvest season by using lower-chill cultivars with short fruit development periods and complementary production in both the northern and the southern hemispheres.

In the low-chill stone fruit breeding programs in the United States, the emphasis is to develop early ripening cultivars to extend the harvest season forward to capture the lucrative early fruit market. In contrast, the Latin American programs, although early cultivars were developed, many mid season and late ripening cultivars were also released to support their local produce/processing industry (Byrne et al., 2000). This work has resulted in increased peach production in many subtropical and tropical regions. Although some of this fruit is destined to be marketed internationally, much is still sold in the regional market. Consequently, for the global market objective, the emphasis is the development of cultivars ripening in April and May in the northern hemisphere and October to mid December in the southern hemisphere, but there is still a need to develop mid and late season cultivars to supply fresh fruit for the local market as generally $90 \%$ to $95 \%$ of the production is consumed locally.

There is a trend toward increased production of medium (350 to 650 chilling units) and low (less than 350 chilling units) chilling cultivars either under protected production systems (China, Japan) or in subtropical and tropical conditions [tropical South America (Brazil, Bolivia, Uruguay, and Ecuador) and northern Africa (Algeria, Egypt, Morocco, and Tunisia)] (Fig. 1). This extends the harvest season forward by $30 \mathrm{~d}$ or more over the traditional high-chill growing regions. This has been made possible by the pioneering work begun in California and continued in Florida. This work was complemented by work in Texas, Louisiana, Mexico, Brazil, and South Africa. In the last 20 years, there has been increased activity in many medium and low-chill breeding programs and additional efforts, both public and private, in Asia (Taiwan, Thailand, China), Australia, California, Spain, and others (Byrne et al., 2000).

Recently there has been a rapid increase in the use of protected culture of stone fruit (mainly peach and nectarine) in China to advance harvest from 20 to $90 \mathrm{~d}$ before field-produced stone fruit. As done in China, the structures are simple and the heat is regulated by ventilation during the day and by insulating mats during the night. Beyond the obvious advantage of early harvest, this type of culture also requires fewer chemical sprays to control pests and diseases and offers good protection against cold injury to the tree and crop, which is a problem in Liaoning Province where this production system is common. Currently the cultivars used are those developed for field production. For more efficient production, specialized cultivars adapted to the greenhouse environment would be best. These would be low- and medium-chill cultivars with a short fruit development period and medium vigor, and the ability to grow well under low light conditions, the ability to set fruit under high temperatures, and high quality since the soluble

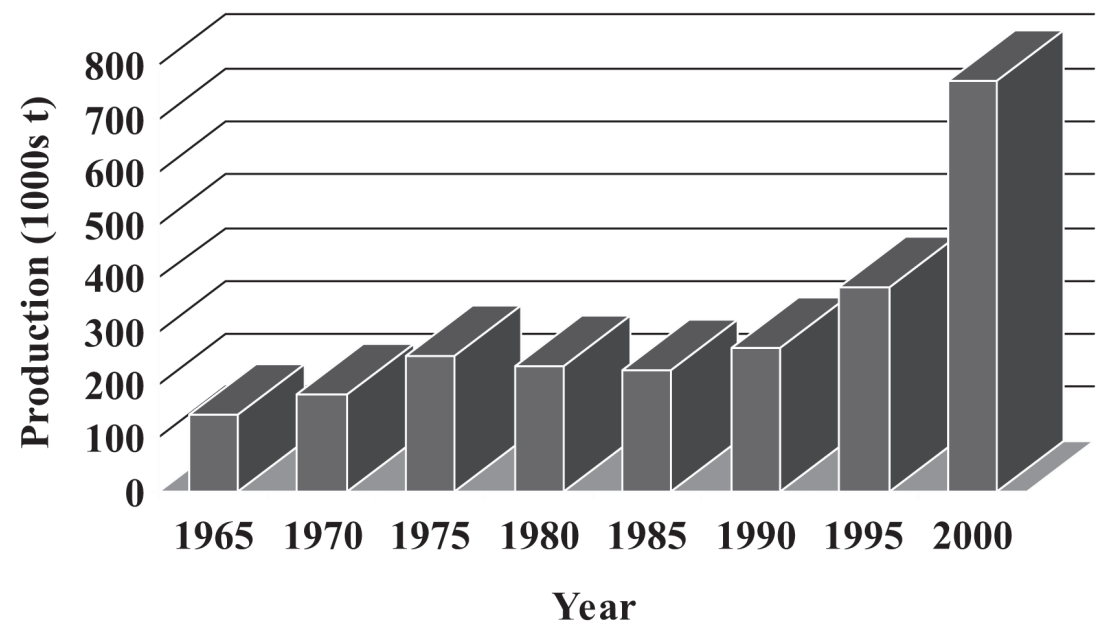

Fig. 1. Peach production in tropical South America and North Africa. Data are from FAOSTAT (Food and Agriculture Organization, 2004) and are 5-year means beginning with the indicated year $(1000 \mathrm{t}=1102.3$ tons $)$. 
solids of protected culture produce fruit is usually $1 \%$ to $2 \%$ lower than field produced fruit (Jiang et al., 2004; L. Wang et al., unpublished).

For frost-free zones, work needs to be done to develop cultivars that can be cropped twice per year or, alternately, cultivars in which the bloom can be easily manipulated to time harvest for specific time periods. Since many of these zones are tropical and warm all year round, low-chill stone fruit that can set under warm conditions are essential for consistent yields (Byrne et al., 2000; Kozai et al., 2004).

In the southern hemisphere (Chile, South Africa, and Australia), there has been a general increase in production of peaches for shipment to the northern hemisphere. Although Chile presently uses mainly California cultivars, there is a need for better-adapted cultivars with excellent postharvest characteristics. Currently, South Africa, Chile, and Australia have active breeding efforts to develop specific cultivars for their export markets (Byrne et al., 2000) and there is much opportunity for the development of low-chill cultivars for the export markets between the hemispheres to supply fruit in April to May and October to December time slots.

\section{Diversification of fruit types}

There is a wide diversity of peach and nectarine types grown in the world. Traditionally regional preferences are linked to fruit types, with Chinese and Japanese markets preferring low-acid white peaches, North American markets wanting yellow-fleshed acid types, and the Spanish and many Latin American markets expecting non-melting yellow-orange peaches. Globalization of the produce market and demands for new produce items are eroding these distinctions with diverse types of peaches evident in most markets.

Over the last 50 years, the supermarket produce section in the U.S. has changed dramatically with a greatly increased number of items sold (Davis and Stewart, 2002). Not only are there more cultivars and types of any given fruit but also there is more competition from exotic fruit and another class of convenience food-the minimally processed fresh product. Fifty years ago in the U.S. the yellow-fleshed acid peach was king and nectarines were a rarity. Now nectarines compose about onehalf of the fresh "peach" production in California (CTFA, 2003). In addition, there are white- and yellow-flesh types, low-acid and high-acid types, and recently we have begun to see flat (pantao) peaches in the supermarkets, and soon we will see red- and orangefleshed peaches and nectarines.

Unfortunately, the consumer is getting confused with the multiple types of items being marketed. Some are buying white peaches or nectarines, expecting a low-acid type flavor and getting a high-acid flavor. As we develop these "new" peaches and nectarines, they need to be differentiated by name so people know what they are buying, especially as it relates to internal quality. An example of this is the "Ghiaccio" (Italian for "ice") series of peaches developed in Italy. These are white, high-soluble-solids, lowacid peaches - very different from the common peach type grown in Europe and the U.S. (Byrne, 2002). Although some breeders have developed naming protocols that correspond to the different fruit types, these have not generally translated into marketing names.

Flat peaches are beginning to enter into the markets of Europe and North America. Although these have been grown in China for centuries, until recently their widespread commercial use has been limited due to a lack of firmness and cracking problems. At present, breeding efforts are being made to develop a series of commercial cultivars in Nanjing (Ma et al., 1999), Zhengzhou (L. Wang, personal communication), and Beijing (Jiang et al., 1999). An excellent series of flat peaches is the Ruipan series developed in Beijing by Jiang Quan and his collaborators. The cultivar that is commercially used in the U.S. is 'Saturn', a cultivar developed by L.F. Hough at Rutgers University (New Brunswick, N.J.) over 30 years ago. More pantao cultivars are actively being developed in the U.S. ('Galaxy' and 'UFO'), France, Italy (UFO series based on crosses with 'Saturn'), and other countries (Byrne, 2002; Sherman and Lyrene, 2000)

\section{Increased interest in the health benefits of fruit}

The health benefits of fruit and other produce always seem to be in the news (Variyam and Golan, 2002). As the public becomes more aware of the health benefits of fruit and is being told to eat a colorful diet, there is a potential to create a new market for cultivars specifically developed for their health benefits. Recent work has shown that carotenoids (orange/yellow pigments), anthocyanins (red pigments), and general phenolics (colorless) found in peaches have antioxidant properties that have protective properties against various pathological conditions such as inflammation, cancer, atherosclerosis, and other circulatory problems (Cevallos-Casals et al., 2002; Gil et al., 2002; Prior and Cao, 2000; Tomas-Barberan et al., 2001; Wargovich, 2000). The healthy-for-you marketing approach is being pursued aggressively to increase consumption of some fresh products, but no stone fruit cultivars have been developed specifically for higher levels of these phytochemicals. Such "healthenhanced" cultivars would provide a new product that could be sold fresh or processed (total crop or as an outlet for the cull fruit) into extracts that are natural sources of antioxidants, antimicrobials, and colorants (Byrne, 2002).

\section{Increased demand for fruit quality}

From 1980 to 2003, per capita consumption of non-citrus fresh fruit in the U.S. increased $17.2 \%$ (Perez and Pollack, 2004) and it is expected to grow another $8 \%$ from 2000 to 2020 (Bliserd et al., 2002). Nevertheless, the per capita consumption of stone fruit in the U.S. has been steady or decreasing over the last 20 years (Perez and Pollack, 2004). Beyond increased competition from new cultivars of standard crops, new exotic fruit, and more minimally processed produce items, an often-cited reason for this trend is the inconsistency of fruit quality of stone fruit.

As compared to other crops such as pome fruit and grapes (Vitis spp.), the quality of stone fruit is quite inconsistent. In various surveys in Southeast Asia, the U.S., and in Europe, inconsistent or poor quality has been cited as a major reason why people do not buy more peaches (Clareton, 2000; Crisosto et al., 2003; Wei, 2001). In France, a full $80 \%$ of the consumers questioned were dissatisfied with the consistency of the peaches that they had bought (Clareton, 2000)! This does not refer to external qualities as these are efficiently standardized by packing, but rather to internal quality (firmness, soluble solids, acidity). 
Currently, sampling within large lots may detect particularly poor lots of fruit. However, to ensure consistently high quality fruit, the testing needs to be done on an individual fruit basis. Work on nondestructive systems to measure quality using acoustical and near infrared systems (Chatjigakis et al., 1998; Peiris et al., 1998) has led to commercial use in a packing line situation. This allows the selection of individual fruit for acceptable fruit quality and puts higher quality standards on the cultivars that are developed. This is essential to increase peach consumption. Unfortunately, peach quality is a complex trait and is dependent on cultural conditions (Crisosto et al., 1997; DeJong et al., 2002) as well as the genetics of the cultivar (Byrne, 2002).

Good fruit firmness is essential for ease of handling and marketing. Whereas the most high-chill freshmarket stone fruit breeding programs have traditionally emphasized the development of melting flesh types for the fresh market, the two Mexican and the Brazilian (Pelotas) programs have worked with non-melting flesh germplasm. This firmer flesh type allows the harvesting at a higher quality, tree-ripe stage with enough firmness to market (Hough, 1985). It should be noted that fresh market cultivars with non-melting flesh have been used for centuries in Latin America and Spain. More recently, this flesh type has been used to develop early ripening cultivars with better firmness and flavor for the fresh market. This approach has been promoted in U.S. by W.B. Sherman of the University of Florida. Fresh market peaches with non-melting flesh released in the U.S. include 'UFGold', 'UFPrince', 'Gulfprince', 'Delta', 'Springprince', 'Springbaby', and 'Crimson Lady' (Byrne, 2002). Recent work has also reported semi-free- to free-stone forms with non-melting flesh, which overcomes a potential problem in the fresh market and would also be a useful trait in the processing market (Beckman and Sherman, 1996; Martinez-Gomez et al., 2003).

Another flesh type being explored is the stony hard flesh found in cultivars such as 'Jingyu' in China. This fruit can be kept at room temperature for $10 \mathrm{~d}$ after harvest, and when eaten appears to be melting flesh. Research shows that this flesh type produces less ethylene and therefore ripens slower
(Byrne et al., 2000; Goffreda, 1992; 1999; Liverani and Giovannini, 2000). L.F. Hough began work with this gene many years ago and now the New Jersey breeding program has some promising selections in this background (Goffreda, 1999). Other flesh types that need to be studied further would be the flesh types described as "crisp" or "crunchy," as seen in the Korean cultivar Yumyeoung and the Italian cultivar Grezzano (Liverani and Giovannini, 2000); and the slow-ripening gene described in the California germplasm derived from the nectarine 'Fantasia' (Brecht and Kader, 1984; Brecht et al., 1984).

Peaches are expected to be sweet and recent surveys indicate that soluble solids less than $10 \%$ for acid cultivars and $11 \%$ for low acid peaches/nectarines are generally unacceptable to consumers (Crisosto et al., 2003). Unfortunately, many common cultivars, especially early ripening cultivars, typically have soluble solid levels of $8 \%$ to $11 \%$. This needs improvement and excellent progress is being made in developing high soluble solids peaches/nectarines for the mid and late season harvest periods. Levels in the $17 \%$ to $20 \%$ range should be possible. There are nectarine cultivars in California and peach cultivars in Italy (Ghiaccio series) that are reported to be in this range (Byrne, 2002; Byrne et al., 2000; Crisosto et al., 1998). Unfortunately, there are breeding obstacles in the development of a peach/ nectarine that is large, early ripening, and has high soluble solids, since total soluble solids generally decrease with lower fruit development period and larger fruit size (Byrne, 2002; Souza et al., 1998, 2000). Nevertheless, recent work in my program and that of the USDA program in California has shown it is possible to combine high soluble solids with good fruit size with a fruit development period of less than $100 \mathrm{~d}$.

Many other factors need consideration as we develop higher quality peach/nectarine cultivars, including aromatic components of flavor, relative amounts of specific sugars (sucrose, glucose, fructose, and sorbitol differ in their sweetness), texture, and acidity. Finally, since the growing practices (pruning, fertility, irrigation, harvesting) have such a great influence on the ultimate quality of the fruit, there is a need to specify the minimal cultural conditions to obtain the highest potential quality of the cultivar.

\section{Need for better postharvest traits}

Another important trend is the increase in convenience foods. In the case of produce there has been a rapid increase in the number of pre-cut minimally processed products in the produce section of the grocery store. Although much of the development has to do with postharvest treatment and packaging strategies to prolong the shelflife of these products, the selection of the appropriate cultivars for these types of uses will be important as this industry develops and expands into the stone fruit arena.

As the produce market becomes more global and a year-round supply of produce is required, fruit cultivars need to have the appropriate postharvest characteristics that allow a shipping/marketing period of several months without losing quality or experiencing internal breakdown. This implies that we need to be able to control the ripening process. A peach that could be harvested mature-ripe, held in storage, and then induced to ripen once put into the retail market would be ideal. In peach there are genes such as stony hard (Goffreda, 1992) and slow ripening (Brecht and Kader, 1984) that control ethylene and the rate of maturation, as are found in tomato (Lycopersicon esculentum), a well-studied fruit ripening system. A promising research approach would be to use the existing information on other crops to understand and identify genes in peach that control ripening (Rasori et al., 2003).

The most common postharvest problem is chilling injury, which includes flesh browning and mealiness (woolliness) (Crisosto et al., 1999). Although much work has been devoted to controlling this problem by manipulating the storage conditions (mainly temperature) (Hartman, 1985), only recently has good data been developed to compare cultivar differences (Brovelli et al., 1998; Crisosto et al., 1999; Kim et al., 1998; Luchsinger and Walsh, 1998). This is the first step in developing rapid evaluation techniques to evaluate seedling trees for their resistance to chilling injury during storage. The physiological and genetic basis of this and other postharvest traits need to be further studied. 


\section{Conclusions}

The peach and other stone fruit have been sold in many different forms throughout the world depending on the preferences of the region. Recent trends in marketing encourage the development of "new" types and products to diversify the market for any given region. Thus the concept of the peach and other stone fruit is expanding to include a wider range of colors, shapes, sizes, and flavors. Expansion of stone fruit consumption will depend on marketing, quality consistency, and the cost of the fruit. Market trends that are impacting stone fruit consumption are the globalization and need for year-round supplies of produce, the high cost of labor, the diversification of the produce department and related products, the health benefits of the fruit, and the safety issues of pesticide use and bacterial contamination of fresh produce. These pressures have renewed interest in production systems to extend the harvest season, to reduce chemical inputs, and to ensure consistent fruit quality. In response, breeders are focusing more efforts on developing cultivars with higher fruit quality, better postharvest fruit characteristics, greater resistance to disease and pests, higher levels of health-benefiting phytochemicals, a greater diversity of fruit types to market, modified tree architecture to facilitate fruit culture, and adaptation to subtropical and tropical regions of the world.

\section{Literature cited}

ASHS. 1997. The Brooks and Olmo register of fruit and nut varieties. 3rd ed. ASHS Press, Alexandria, Va.

Bassi, D., A. Dima, and R. Scorza. 1994. Tree structure and pruning response of six peach growth forms. J. Amer. Soc. Hort. Sci. 119:378-382.

Beckman, T.G. and P.L. Pusey. 2001. Field testing peach rootstocks for resistance to armillaria root rot. HortScience 36:101-103.

Beckman, T.G. and W.B. Sherman. 1996. The non-melting semi-freestone peach. Fruit Var. J. 50:189-193.

Bellini, E., L. Natarelli, V. Nencetti, G. Surico, and L. Mugnai. 1996. Peach genetic improvement: Results achieved with a breeding programme for resistance to Taphrina deformans (BERK. TUL.). Acta Hort. 374:33-37.

Bliserd, N., B-H. Lin, J. Cromartie, and N. Ballenger. 2002. America's changing appetite: Food consumption and spending to 2020. Food Rev. 25:2-9.

Brecht, J.K. and A.A. Kader. 1984. Ethylene production by fruit of some slow ripening nectarine genotypes. J. Amer. Soc. Hort. Sci. 109:763-767.

Brecht, J.K., A.A. Kader, and D.W. Ramming. 1984. Description and postharvest physiology of some slow-ripening nectarine genotypes. J. Amer. Soc. Hort. Sci. 109:596-600.

Brovelli, E.A., J.K. Brecht, W.B. Sherman, and C.A. Sims. 1998. Anatomical and physiological responses of melting- and nonmelting-flesh peaches to postharvest chilling. J. Amer. Soc. Hort. Sci. 123:668-674.

Byrne, D.H. 2002. Peach breeding trends: A world wide perspective. Acta Hort. 592:49-59.

Byrne, D.H., W.B. Sherman, and T.A. Bacon. 2000. Stone fruit genetic pool and its exploitation for growing under warm climatic conditions, p. 157-230. In: A. Erez (ed.). Temperate fruit crops in warm climates. Kluwer Academic Publ., Dordrecht, The Netherlands.

California Tree Fruit Agreement. 2003. 2003 Annual report. California Tree Fruit Agreement, Reedley.

Cevallos-Casals, B.A., D.H. Byrne, L. Cisneros-Zevallos, and W.R. Okie. 2002. Total phenolic and anthocyanin content in red-fleshed peaches and plums. Acta Hort. 592: 589-592.

Chatjigakis, A.K., C. Pappas, N. Proxenia, O. Kalantzi, P. Rodis, and M. Polissiou. 1998. FT-IR spectroscopic determination of the degree of esterification of cell wall pectins from stored peaches and correlation to textural changes. Carbohydrate Polymers 37:395-408.

Clareton, M. 2000. Peach and nectarine production in France: Trends, consumption, and perspectives. Summaries. Prunus Breeders Mtg., 2000. Empresa Brasileira de Pesquisa Agropecuária, Clima Temperado. Pelotas (RS). Brazil. 29 Nov.-2 Dec. 2000. p. 83-91.

Claverie, M., N. Bosselut, A.C. Lecouls, R. Voisin, B. Lafargue, C. Poizat, M. Kleinhentz, F. Laigret, E. Dirlewanger, and D. Esmenjaud. 2004. Location of independent root-knot nematode resistance genes in plum and peach. Theor. Appl. Genet. 108(4):765-773.

Crisosto, C., G. Crisosto, and E. Bowerman. 2003. Searching for consumer satisfaction: New trends in the California peach industry. Proc. 1st Mediterranean Peach Symp. 10 Sept. 2003, Arigento, Italy.

Crisosto, G., C. Crisosto, and M. Watkins. 1998. Chemical and organoleptic descrip- tion of white flesh nectarines and peaches. Acta Hort. 465:497-505.

Crisosto, C., R.S. Johnson, and T.M. DeJong. 1997. Orchard factors affecting postharvest stone fruit quality. HortScience 32:820-823.

Crisosto, C., F. Mitchell, and Z. Ju. 1999. Susceptibility to chilling injury of peach, nectarine, and plum cultivars. HortScience 34:1116-1118.

Davis, D.E. and H. Stewart. 2002. Changing consumer demands create opportunities for U.S. food system. Food Rev. 25:19-23.

DeJong, T.M., R.S. Johnson, D. Bryla, J.F. Doyle, and D. Ramming. 2002. Evaluation of size controlling rootstocks for California peach production. 2001 Res. Rpt., California Tree Fruit Agreement, Reedley. p. 113-120.

Della Strada, G. and C. Fideghelli. 2003. Le cultivar de drupacee introdottee del 1991 al 2001. L'Informatore Agrario 41:65-70.

Della Strada, G., C. Fideghelli, and F. Grassi. 1996. Peach and nectarine cultivars introduced in the world from 1980 to 1992. Acta Hort. 374:43-51.

Dimitri, C. and C. Greene. 2002. Recent growth patterns in the U.S. organic food market. USDA, Econ. Res. Serv. Agric. Info. Bul. 777.

Food and Agriculture Organization. 2004. FAOSTAT data. 5 July 2004. <http://faostat.fao.org/faostat/form? collection=Prod uction. Crops.Primary\&Domain=Productio n\&servlet $=1$ \&language $=\mathrm{EN} \&$ hostname $=\mathrm{a}$ pps.fao.org\&version=default $>$.

Fideghelli, C., G. Della Strada, F. Grassi, and G. Morico. 1998. The peach industry in the world: Present situation and trend. Acta Hort. 465:29-39.

Foulongne, M., T. Pascal, F. Pfeiffer, and J. Kervella. 2003. QTLs for powdery mildew resistance in peach $\mathrm{x}$ Prunus davidiana crosses: consistency across generations and environments. Mol. Breeding New Strategies in Plant Improvement 12(1):33-50.

Frey, K.J. 1996. National plant breeding study: I. Human and financial resources devoted to plant breeding research and development in the United States in 1994. Spec. Rpt. 98. Iowa State Univ., Ames.

Frey, K.J. 1998. National plant breeding study. III. National plan for gene pool enrichment of U.S. crops. Spec. Rpt. 101. Iowa State Univ., Ames.

Gil, M.I., F.A. Tomas-Barberan, B. HessPierce, and A.A. Kader. 2002. Antioxidant capacities, phenolic compounds, carotenoids, and vitamin C contents of nectarine, peach, and plum cultivars from California. J. Agr. Food Chem. 50:4976-4982. 
Giovannini, D., D. Glenn, R. Scorza, and W. Welker. 1994. Dry matter distribution of three peach growth types. HortScience 29:1481-1483.

Goffreda, J.C. 1992. Stony hard gene of peach alters ethylene biosynthesis, respiration, and other ripening related characteristics. HortScience 27:122

Goffreda, J.C. 1999. White-fleshed peach and apricot breeding. Compact Fruit Tree $32: 123-127$.

Gradziel, T.M., M.A. Thorpe, R.M. Bostock, and S. Wilcox. 1998. Breeding for brown rot (Monilinia fructicola) resistance in clingstone peach with emphasis on the role of fruit phenolics. Acta Hort. 465:161-169.

Hartmann, P. 1985. Research on wooliness in peaches and nectarines during the 1984-85 season. Deciduous Fruit Grower 35:194-198.

Hough, L.F. 1985. Perspectives for peach breeding for the cultivars for $2000 \mathrm{AD}$. Acta Hort. 173:11-20.

Jiang, Q., J. Guo, and S. Zheng. 1999. 'Ruipan No. 4'-A late ripening flat peach (Chinese). Acta Hort. Sinica 26:277.

Jiang, W., D. Qu, D. Mu, and L.R. Wang. 2004. China's energy saving greenhouses. Chronica Hort. 44:15-17.

Kervella, J., F. Pfeiffer, L. Pages, M. Genard, and V. Serra. 1998a. Taking into account relationships between ecophysiological processes in the breeding for peach tree characteristics. Acta Hort. 465:145-154.

Kervella, J., T. Pascal, F. Pfeiffer, and E. Dirlewanger. 1998b. Breeding for multiresistance in peach tree. Acta Hort. 465:177-184.

Kim, I., J. Byun, J. Cho, Y. Choo, S. Kim, and B. Choi. 1998. Evaluation of storage ability of peach cultivars by storage temperature and polyethylene film packing (Korean). Rural Dev. Admin. J. Hort. Sci 40:41-46.

Kozai, N., K. Beppu, R. Mochioka, U. Boonprakob, S. Subhadrabandhu, and I. Kataoka. 2004. Adverse effects of high temperature on the development of reproductive organs in 'Hakuho' peach trees. J. Hort. Sci. Biotechnol. 79:533-537.

Lang, G.A. 2000. Precocious, dwarfing, and productive-How will new cherry rootstocks impact the sweet cherry industry? HortTechnology 10:719-725.

Lecouls, A.C., V. Bergougnoux, M. J. Rubio-Cabetas, N. Bosselut, R. Voisin, J. L. Poessel, M. Faurobert, A. Bonnet, G. Salesses, and E. Dirlewanger. 2004. Markerassisted selection for the wide-spectrum resistance to root-knot nematodes conferred by the Ma gene from Myrobalan plum (Prunus cerasifera) in interspecific Prunus material. Mol. Breeding New Strategies in Plant Improvement 13(2):113-124.

Liverani, A. and D. Giovannini. 2000. The peach breeding program at the Istituto Sperimentale per la Frutticultura di Forli (Italy). Summaries. Prunus Breeders Mtg., 2000. Empresa Braseilera de Pesquisa Agropecuária, Clima Temperado. Pelotas (RS). Brazil. 29 Nov. 29-2 Dec. 2000. p. 19-23.

Lu, Z-X., G.L. Reighard, A.P. Nyczepir, T.G. Beckman, and D.W. Ramming. 2000. Inheritance of resistance to root-knot nematodes (Meloidogynesp.) in Prunusrootstock. HortScience 35:1344-1346.

Luchsinger, L. and C. Walsh. 1998. Chilling injury of peach fruit during storage. Acta Hort. 464:473-477.

Ma, R., M. Yu, X. Yang, and P. Du. 1999. New flat peach varieties: Zaoshuomi and Zaokuimi (Chinese). China Fruits 4:7-8.

Martinez-Gomez, P., S. Arulsekar, D. Potter, and T.M. Gradziel. 2003. An extended interspecific gene pool available to peach and almond breeding as characterized using simple sequence repeat (SSR) markers Euphytica 131(3):313-322.

Monet, R., Y. Bastard, and B. Gibault. 1988. Etude genetique du caractere "port pleureur" chez le pecher. Agronomie 8:127-132.

Monet, R., A. Guye, and G. Massonie. 1998. Breeding for resistance to green peach aphid, Myzus persicae Sulzer in the peach. Acta Hort. 465:171-175.

Nyczepir, A.P. and T.A. Beckman. 2000. Host status of Guardian peach rootstock to Meloidigyne sp. and M. javanica. HortScience 35:772.

Okie, W.R. 1998. Handbook of peach and nectarine varieties. USDA. Agr. Hdbk No. 714

Pascal, T. and R. Monteux-Caillet. 1998. Peach breeding in France. Acta Hort. 465:117-123.

Peiris, K.H.S., G.G. Dull, R.G. Leffler, and S.J. Kays. 1998. Near-infrared spectrometric method for nondestructive determination of soluble solids content of peaches. J. Amer. Soc. Hort. Sci. 123:898-905.

Perez, A. and S. Pollack. 2004. Fruit and tree nuts. Situation and outlook yearbook. USDA. Econ. Res. Serv. FTS-2004.

Pinochet, J., C. Fernandez, C. Calvet, A. Hernandez-Dorrego, and A. Felipe. 2000. Selection against Pratylenchus vulnus population attacking Prunus rootstocks. HortScience 35:1333-1337.

Prior, R.L. and G. Cao. 2000. Antioxidant phytochemicals in fruits and vegetables: Diet and health implications. HortScience 35:588-592.
Rasori, A., B. Bertolasi, A. Furini, C. Bonghi, P. Tonutti, and A. Ramina. 2003. Functional analysis of peach ACC oxidase promoters in transgenic tomato and in ripening peach fruit. Plant Sci. 165(3):523-530.

Reighard, G.L. 2000. Peach rootstocks for the United States: Are foreign rootstocks the answer? HortTechnology 10:714-718.

Scorza, R. 1987. Identification and analysis of spur growth in peach (Prunus persica L. Batsch). J. Hort. Sci. 62:449-455.

Scorza, R. 2000. Progress in tree fruit improvement through molecular genetics. HortScience 36:855-858.

Scorza, R., L. Zailong, G.W. Lightner, and L.E. Gilreath. 1986. Dry matter distribution and responses to pruning within a population of standard, semidwarf, compact, and dwarf peach seedlings. J. Amer. Soc. Hort Sci. 111:541-545.

Scorza, R., G.W. Lightner, and A. Liverani. 1989. The pillar peach tree and growth habit analysis of compact $\times$ pillar progeny. J. Amer. Soc. Hort. Sci. 114:991-995.

Sherman, W.B. and P. Lyrene. 2000. 'UFO' a saucer or donut peach. J. Amer. Pomol. Soc. $55: 2-3$

Souza, V., D.H. Byrne, and J.F. Taylor. 1998. Heritability, genetic and phenotypic correlations, and predicted selection response of quantitative traits in peach: II. An analysis of several fruit traits, J. Amer. Soc. Hort. Sci. 123:604-611.

Souza, V., D.H. Byrne, and J.F. Taylor. 2000. Predicted breeding values for nine plant and fruit characteristics of 28 peach genotypes. J. Amer. Soc. Hort Sci. 125:460-465.

Tomas-Barberan, F.A., M.I. Gil, P. Cremin, A.L. Waterhouse, B. Hess-Pierce, and A.A. Kader. 2001. HPLC-DAD-ESIMS analysis of phenolic compounds in nectarines, peaches, and plums. J. Agr. Food Chem. 49:4748-4760.

Tworkoski, T. and R. Scorza. 2001. Root and shoot characteristics of peach trees with different growth habits. J. Amer. Soc. Hort. Sci. 126:785-790.

Variyam, J.N. and E. Golan. 2002. New health information is reshaping food choices. Food Rev. 25:13-18.

Wargovich, M.J. 2000. Anticancer properties of fruits and vegetables. HortScience $35: 573-575$

Wei, S. 2001. Singapore and Hong Kong market research for early season stone fruit. Austral. Fresh Stone Fruit Quarterly $3(1): 8-12$.

Yamamoto, T., and T. Hayashi. 2002. New root-knot nematode resistance genes and their STS markers in peach. Sci. Hort. 96:81-90. 